\title{
Ekonomisk brottslighet; tur och retur
}

\author{
Av Lars Korsell ${ }^{l}$
}

\begin{abstract}
Economic crime has been an important field for political initiatives during the last forty years. This article explores the major trends in legislation and how law enforcement agencies have been organized. In the 1970s, economic and organized crime were more or less treated as a common problem. The connection between economic and organized crime is still emphasized. Investigative measures from organized crime control are also used to fight economic crime. Intelligence services and wiretapping are new tools against white-collar criminals. Asset recovery and a multidisciplinary approach have improved the cooperation between agencies. The Tax Administration, the Enforcement Agency and the Social Insurance Agency have become key players.

"New economic offences have been important on the political agenda: corruption, financial crimes and social benefits fraud. Fraud in general is likely to be an important criminal problem in the future. Several of the offences which get a lot of attention are not investigated by the Economic Crime Agency. This may cause political initiatives to be focused more narrowly on specific problems like corruption instead of »economic crime« more generally."
\end{abstract}

\section{Inledning}

Vilka trender ser vi i dagens ekobrottsbekämpning? Hur kommer framtidens kriminalpolitik på ekobrottsbrottsområdet att gestalta sig? Det är två frågor som denna artikel diskuterar, med ett avstamp i de senaste fyrtio årens initiativ mot denna kriminalitet.

Det var först under 1970-talet som ekonomisk brottslighet blev en politisk fråga (Lindgren 2000, Korsell 2006). Den verkliga kriminalpolitiska »braständaren « stod en arbetsgrupp för inom Rikspolisstyrelsen med samverkande myndigheter AMOB-utredningen. Siffror sattes på skattebrottsligheten (AMOB 1977). Det skulle röra sig om 5-20 miljarder kronor om året i den tidens penningvärde

* Title in English: Economic Crime; Back and Forth. 
(Svensson 1982). Den första kriminalpolitiska högkonjunkturen på ekobrottsområdet hade inletts.

Holger Romander, som vid den tiden var rikspolischef, menade att det dröjde »förvånansvärt länge« innan ekobrotten gjorde »synliga avtryck i praktisk kriminalpolitik« (Romander 2000:30). Nu var dock stenen i rullning. Brottsförebyggande rådet (Brå) fick i uppdrag att se över lagstiftningen och tog fram en rad konkreta lagförslag både mot ekonomisk och organiserad brottslighet (Romander 2000).

I början av 1980-talet tillsatte regeringen en särskild Eko-kommission som skulle föreslå lämpliga åtgärder mot »ekonomisk brottslighet och skatteflykt« (dir. 1982:101). Den skilde sig från AMOB och Brå på två plan. AMOB och Brå hade ett bredare perspektiv än Eko-kommissionen genom att se organiserad och ekonomisk brottslighet som ett delvis sammanhängande fenomen (Lindgren 2000). De åtgärder och förslag som togs fram riktades följaktligen mot organiserad brottslighet, ekonomisk brottslighet och den inte obetydliga gråzon där emellan (jfr. Korsell, Skinnari och Vesterhav 2009, Ruggiero 1996). Eko-kommissionen var enbart inriktad mot ekonomisk brottslighet, och som redan framgick av direktiven fanns en slagsida mot skatter.

I likhet med Brå-översynen lade Eko-kommissionen fram en rad förslag, men åtskilliga av dessa hamnade dock i departementens skrivbordslådor. En förklaring var att kommissionen redan från början uppfattades som kontroversiell och fick en negativ stämpel (Nord 2000). Ett förslag som aldrig genomfördes var kravet på näringstillstånd (vandelsprövning, utbildningskrav och ekonomiska garantier för skatter och avgifter) för att få driva företag i särskilt utsatta branscher för ekonomisk brottslighet. Som senare kommer att utvecklas belyser tanken på näringstillstånd väl de tongångar som fanns vid denna tid, men som idag anses hopplöst förlegade.

Mot mitten av 1980-talet gick luften ur ekobrottsfrågorna (Lindgren 2000). Det dröjer dock inte många år förrän det återigen skulle våras för ekobrotten. Det glada 1980-talet bäddade för nästa renässans. Spekulation, finansvalpar och nyrikedom slutade illa med bankkris, prisras på bostadsmarknaden och masskonkurser (Alalehto 2003). I början av 1990-talet riktade Riksdagens revisorer kritik över insatserna mot den ekonomiska brottsligheten (1993/94:6 och 1994/95:RR4). Revisorernas rapport blev startskottet för ett omfattande reformarbete. Själva kronjuvelen i 1990-talets insatser var att Ekobrottsmyndigheten bildades (Ds 1996:1, EBM-utredningen 1997). Mindre kända är de samtidigt inrättade skattebrottsenheterna inom Skatteverket (RSV 1995:9, Ds 1997:23). Det är dock svårt att förstå hur dessa reformer kunde genomföras samtidigt eftersom 
de överbryggar varandra $i$ fråga om att utreda skattebrott och närliggande brott (Korsell 2000). Kanske var Finansdepartementet trött på att skattebrotten hanterades illa av rättsväsendet och ville ha en egen »skattepolis«. Riksdagens skatteutskott (bet. 1997/98:SkU10) beskrev att

»Bakgrunden till förslaget om skattebrottsenheter är framför allt att de rättsvårdande myndigheterna under en lång följd av år misslyckats med att få till stånd en långsiktigt fungerande organisation för att bekämpa skattebrott.«

Med tiden har skattebrottsenheterna fătt större polisiära befogenheter (Korsell 2012). Det som i princip återstår innan skattebrottsutredarna i praktiken förvandlas till skattepoliser är beväpning och rätten att använda våld. Träffande nog var titeln på den departementspromemoria där förslaget om skattebrottsenheter lanserades »Skattekriminal« (Ds 1997:23).

\section{Finansiell brottslighet och tillgångsinriktad brottsbekämpning}

En fråga som varken AMOB-utredningen, Brå:s lagstiftningsöversyn eller Ekokommissionen grubblade över var förekomsten av oegentligheter på de finansiella marknaderna. På det internationella planet har dock brottslighet på dessa marknader tilldragit sig större uppmärksamhet. Redan när Edwin Sutherland (1949) på fyrtiotalet skrev sin bok »White-Collar Crime« påtalades denna brottslighet.

Personer $\mathrm{i}$ insiderställning (styrelseledamöter etc.) har tillgång till hemlig information eller uppgifter som annars inte är kända och som kan påverka kursen på finansiella instrument. Frestelsen för personer i insiderställning är givetvis att dra nytta av försprånget och köpa eller sälja innan nyheten blir känd. De första insiderreglerna infördes på 1970-talet då vissa personer med insiderställning blev skyldiga att anmäla innehav och förändringar av aktier i noterade bolag (Boström och Nilsson 2006). Först under 1990-talet och som en följd av EU-inträdet infördes den första insiderlagen (Hetzler 2001, Wesser 2001). Den innehöll förbud mot insiderhandel. Vidare infördes bestämmelser om otillbörlig marknadspåverkan, som bestraffar manipulation av kurserna.

Ett av Ekobrottsmyndighetens stora profilområden har blivit dessa finansiella brott. Det var ett från början marginellt brottsområde, men som fått allt större betydelse i takt med att de finansiella marknaderna vuxit. År 2002 anmäldes sju insiderbrott. År 2011 anmäldes 139 brott. En kraftig ökning på en tioårsperiod som också speglar ändrad lagstiftning och förbättrad kontroll. På liknande sätt har anmälningarna om marknadsmissbruk ökat från 66 år 2009 till 297 år 2011. 
För några år sedan var det nära att Ekobrottsmyndigheten skulle läggas ned enligt ett förslag från en statlig utredning (SOU 2007:8).

»Men just när det såg som mörkast ut avslöjades en av Sveriges största insiderhärvor. Champagneflaskor i 75000 kronorsklassen blev sinnebilden för ekobrottens extravagans och uppmärksamheten kring ekonomisk brottslighet exploderade."

Det skrev kriminalreportern Terese Cristiansson i en krönika år 2009. I fonden fanns också en rad internationella skandaler och fler skulle komma: Nick Leeson spekulerade bort Barings Bank och i företagen Enron och Worldcom upptäcktes allvarliga bokföringsbrott, som också fick med sig revisionsjätten Arthur Andersen $i$ fallet.

Även om Ekobrottsmyndighetens framgångar i domstol inte varit alltför imponerande, framstod myndigheten som en garant mot insiderbrott och marknadspåverkan. Det blev politisk omöjligt att inte fortsätta ta krafttag mot den hotande finansiella brottsligheten. Då var det detsamma som att inte lägga ned Ekobrottsmyndigheten. Nyligen har en utredning föreslagit att Ekobrottsmyndigheten ska utvidga sitt mandat från i stort sett de tre storstadsområdena till hela riket (SOU 2011:47).

Ett annat område som Ekobrottsmyndigheten profilerat sig på är tillgångsinriktad brottsbekämpning. Det handlar om att spåra och återföra vinning av brott. Traditionellt har de brottsbekämpande myndigheterna inte haft som drivkraft att "gå på pengarna« (Brå 2008:10, Brå 2011:4). I stället är det fängelseår som räknas och får uppskattning hos kollegor och chefer. Om något tas i beslag ska det vara smuggelgods eller vapen. År 2007 bildade Ekobrottsmyndigheten en brottsutbytesenhet. Härigenom var Ekobrottsmyndigheten tidig med att organisatoriskt lyfta fram en ny nisch inom brottsbekämpningen.

Nära koppling till tillgångsinriktad brottsbekämpning är åtgärder mot penningtvätt. Ofta förknippas penningtvätt med att dölja pengars ursprung (Örnemark Hansen 1998). Ett klassiskt exempel är hur stora mängder små valörer från narkotikaförsäljning tvättas i de finansiella systemen för att sedan kunna användas för legitima investeringar i företag och fastigheter. I själva verket är behovet av penningtvätt inom organiserad brottslighet i Sverige tämligen begränsat (Brå 2007:4). Vad som är vanligare är att vita pengar smutsas ned genom att användas till svarta löner (Brå 2008:10, Brå 2011:7). Det betyder samtidigt att insatserna mot penningtvätt $i$ hög grad riktar sig mot skattebrott.

Ett omfattande rapporteringssystem har inrättats där banker, växlingskontor, fastighetsmäklare, bilhandlare och många andra branscher och yrkesgrupper är 
skyldiga att till Finanspolisen rapportera misstänkta transaktioner. Finanspolisens penningtvättsregister har mer och mer blivit en viktig informationskälla om svart och kriminell ekonomi (Brå 2011:4).

Penningtvätt förknippas ofta med skatteparadis, där tillgångar kan gömmas utan besvärande frågor. Internationellt har insatserna mot skatteparadis intensifierats och en förklaring är »kriget mot terrorism«. Sverige träffar avtal med skatteparadis om informationsutbyte. Allt färre vita fläckar finns på kartan över länder utan sådana avtal.

På ett annat sätt än tidigare har pengarna kommit i förgrunden för brottsbekämpningen.

\section{Försäkringskassan, en ny aktör}

Även andra myndigheter har visat framfötterna med att arbeta tillgångsinriktat. Myndigheter som Kronofogden och Försäkringskassan har rent av fătt ökad status genom att förknippas med polis- och åklagarväsendet. För tjugo år sedan hade knappast en ekopolis någon större förståelse för att Försäkringskassan skulle ha en roll i kriminalpolitiken. I dag är läget annorlunda och Försäkringskassan uppfattas som en viktig aktör (jfr. Brå 2008:6). Det handlar inte enbart om att ompröva bidrag som går till personer med dokumenterad arbetsförmåga stor nog att ägna sig åt omfattande brottslig verksamhet (Brå 2005:10, Brå 2007:4). På senare tid har också stora härvor med bedrägerier kring assistansersättning uppdagats (ISF 2011:12).

Statusen har också höjts hos skattetjänstemännen till följd av deras kompetens på frågor om ekonomi och företagande. Inom ekobrottsbekämpningen är det en självklarhet. Det nya är att Skatteverket uppfattas som en allt viktigare aktör för bekämpning av organiserad brottslighet. Skattevapnet är effektivt och det är lättare bevisbörderegler i skatteprocessen jämfört med brottmål.

Delvis nya aktörer har kommit in på ekobrottsbekämpningens spelplan, och det är pengarna som är i centrum.

\section{Organiserad brottslighet är högsta mode}

Under senare delen av 1990-talet och ännu mer i dag har frågor om organiserad brottslighet överskuggat ekobrottsligheten. Utvecklingen av gäng, inte minst inom mc-miljön, spektakulära kupper som helikopterrånet i Stockholm, sprängattentat mot en åklagare och skjutningar på öppen gata har bidragit till att de mer stillsamma ekobrotten hamnat i bakgrunden. Trustor-mannen och ekobrottslingen Joakim Poseners bok (2004) kan i dramatik knappast mätas med skildringar av 
den organiserade brottsligheten med titlar som »Svensk maffia« och »Maffiakrig « (Korsell 2008 och 2010).

Det går inte att undgå misstanken att uppmärksamheten kring organiserad brottslighet har fört med sig att ekobrottsförespråkarna mer och mer börjat betona kopplingen mellan ekonomisk och organiserad brottslighet för att visa sin relevans. Ett begrepp som används är organiserad ekonomisk brottslighet. Samtidigt är kopplingen mellan ekonomisk och organiserad brottslighet en realitet. I kampen mot organiserad brottslighet är en nationell prioritering »företag i brottslig verksamhet« (Brå 2011:20). Under 2000-talet sker sedan en rad förändringar där sambandet mellan ekonomisk och organiserad brottslighet på olika sätt manifesteras.

Ett exempel är att myndigheter med inriktning på ekonomisk brottslighet tagit intryck av hur organiserad brottslighet bekämpas. Tidigare förekom inte telefonavlyssning mot grova skattebrottslingar. Hemliga tvångsmedel ansågs vara ett medel mot framför allt organiserad narkotikabrottslighet. När Ekobrottsmyndigheten började avlyssna personer involverade i skattebrottslighet visade det sig att de utgick från att de inte var avlyssnade (Brå 2007:27). Det är stor skillnad mot gärningspersoner inom traditionell organiserad brottslighet, som räknar med att de är ständigt avlyssnade och därför som regel mycket försiktiga med vad de säger i telefon (SOU 2012:44).

Ytterligare en inspirationskälla från fältet organiserad brottslighet är betoningen på underrättelseverksamhet. Organiserad brottslighet är långsiktig och bygger på förberedelser, logistik och kontakter. Det handlar om nätverk av personer som gång på gång upprepar sina brott (Brå 2011:7). Därför är det också möjligt att följa personers och grupperingars göranden och låtanden. Det dröjde dock innan Ekobrottsmyndigheten och skattebrottsenheterna började bygga upp sina underrättelsetjänster. Då hade också underrättelseverksamhet blivit en statusfråga och »alla« skulle ha underrättelsetjänster.

Uppmärksamheten mot organiserad brottslighet har också inneburit en kraftig satsning från regeringens sida. Det började med att Polisen år 2006 frigjorde 120 miljoner kronor som användes för att genomföra polisiära projekt mot den organiserade brottsligheten runt om i landet (Brå 2009:19). Även om viss samverkan skedde med andra myndigheter var det bara Polisen som kunde få del av de öronmärkta medlen. Bakom fantasifyllda kodnamn som »Playa«, »Las Vegas« och »Fatboy« dolde sig kraftsamlingar med telefonavlyssning och uthålliga spaningsinsatser mot olika konstellationer. Pengarna räckte till 43 projekt. Det skulle snart visa sig att 120-miljonerssatsningen enbart var ett förspel, och att ekobrotten med tiden skulle få ett större inflytande. 
År 2009 genomförs en myndighetsgemensam satsning mot organiserad brottslighet (Brå 2011:20). Inom Polisen inrättas åtta aktionsgrupper runt om i landet med 200 polisanställda. Tidigare har Göteborg, Malmö och Stockholm etablerat regionala underrättelsecentra. I och med satsningen bildas ytterligare centra, som nu finns på åtta orter i landet. Det unika med dessa centra är att underrättelsehandläggare från en rad myndigheter samverkar i samma lokal. Inte minst är ekobrottsinslaget tungt med företrädare från både Ekobrottsmyndigheten, Skatteverket, Tullverket och Kronofogden. Försäkringskassan ingår också i några centra. På nationell nivå finns ett nationellt underrättelsecenter (NUC).

Framför allt genom samarbetet i regionala underrättelsecentra har ekobrottsbekämpningen fått en bredare plattform. De problem som tidigare betonats att gärningspersonerna inte gör samma uppdelning av myndigheterna i en ekobrottsoch en organiserad brottslighetsfalang kan i någon mån lindras genom dessa underrättelsecentra.

\section{Korruption}

Vid sidan av finansiella brott, tillgångsinriktad brottsbekämpning och organiserad brottslighet har korruption vuxit i kriminalpolitisk betydelse. År 2003 inrättade Åklagarmyndigheten en riksenhet mot korruption som utreder och lagför korruptionsbrott över hela landet (Brå 2007:21). Sent omsider har polisen vaknat, och inom Rikskriminalpolisen har nu en utredningsfunktion bildats. Tidigare hade åklagarväsendet riktat stark kritik mot att polisens utredningsresurser varit otillräckliga (SVT 2009). Det är inte svårt att stämma in i åklagarnas kritik när ett stort exportland som Sverige gör affärer över hela världen och följaktligen också i länder där korruption är vanligt förekommande (jfr. Wästerfors 2004). Inte minst gäller det korruption i anslutning till känsliga affärsområden som vapenhandel, utvinning av olja och storskaliga byggnads- och anläggningsarbeten (Brå 2007:21).

Även om antalet korruptionsärenden ligger förhållandevis konstant över åren finns i dag en större medvetenhet om att även Sverige är drabbat av mutor och att personer höjda över alla misstankar visar sig vara vårdslösa med allmänna medel (Statskontoret 2012:20). På senare tid har korruptionsärenden inom den kommunala förvaltningen i Göteborg avlöst varandra. Flera av dessa fall gäller upphandling av byggtjänster, ett klassiskt område för korruption (Brå 2007:21). Denna följetong har gjort att begreppet Göteborgsandan fått en ny innebörd på liknande sätt som Motala fortfarande förknippas med mygel inom den politiska ledningen (Citron 1999, Ludvigsson 2008). Det är dock orättvist att peka ut vissa orter för ett i grunden strukturellt problem som finns på många andra håll, dock (ännu) inte 
upptäckta. Dessa två exempel visar ändå hur några ekobrott kan påverka en hel kommuns rykte och på nolltid spoliera åratals av ansträngningar för att bygga upp en stads image. Även »Skandinaviens huvudstad« är involverat i korruptionsanklagelser, kring ett arenabygge i Solna.

Korruption drabbar även myndigheters anseende. I Kriminalvårdens nya anstalt Saltvik utanför Sandviken, med landets högsta säkerhet, upptäcktes allvarliga oegentligheter i samband med upphandlingen (Lisinski 2010). Frågan många ställer är om de skummaste figurerna finns i cellerna eller på fängelsekontoret.

\section{Bedrägerier}

Om korruption fått stor kriminalpolitisk betydelse gäller inte detsamma för bedrägerier. Det är en brottslighet som täcker »vanliga« människors fusk med sjukskrivning eller vård av sjukt barn, yrkeskriminellas beställning av varor som aldrig betalas och ekobrottslingars förslagna upplägg med bluffakturor och påhittade investeringsobjekt. Spännvidden är stor, vilket kan vara en förklaring till att bedrägerier aldrig riktigt hittat någon fast tillhörighet $\mathrm{i}$ de satsningar som gjorts mot den ekonomiska brottsligheten. Det är också skälet till att det har varit svårt att göra politik av bedrägerier.

Intrycket är att bedrägerier hanteras styvmoderligt av rättsväsendet. Det kommer att visa sig vara ett misstag eftersom det knappast finns någon brottslighet som visar samma ökning i procent och antal i kriminalstatistiken. Sedan år 2002 har antalet anmälningar av bedrägerier nästan tredubblats från drygt 40000 till knappt 120000 .

I dag är förutsättningarna betydligt större för att begå bedrägerier än när »Stockholmsdetektiven « gavs ut år 1893, Sveriges första detektivroman med bedrägeri som tema. Det är också billigt genom tillgången på datorer för att framställa »originalhandlingar«, skapa imponerande hemsidor och göra massutskick med erbjudanden. Mycket talar också för att bedrägerier är något av »framtidens brottslighet«. I det kontantlösa samhället blir det intressant att genom vilseledande förmå människor, myndigheter och företag att föra över pengar eller egendom till andra. Kort och näthandel skapar också förutsättningar för kapade identiteter och att sälja eller köpa utan att prestera.

\section{Bidragsfusk}

På ett område har dock bedrägerierna på senare tid fått stor uppmärksamhet. Det är på välfärdsområdet, med bedrägerier mot Försäkringskassan och andra bidragsgivare (Jonsson 2010, Korsell, Hagstedt och Skinnari 2008, SOU 2008:74). Nya brott har till och med införts - bidragsbrott och vårdslöst bidragsbrott - ge- 
nom bidragsbrottslagen, som också innebär en markering från statsmakternas sida att det handlar om brott och inte om fusk, som annars var ett vedertaget begrepp.

Förutom vissa politiska utspel, framför allt på högerkanten, började ljuset försiktigt riktas mot bidragsbrott med Riksrevisionsverkets rapport »Fusk - systembrister och fusk i välfärdssystemet« (RRV 1995:32). Även om fusket i procent räknat inte var uppseendeväckande, blev det ändå stora belopp med hänsyn till de stora bidragsvolymerna. Då beräknades överutnyttjande, fusk och systembrister uppgå till mellan 5 och 7 miljarder kronor om året. Uppskattningar pekar på att motsvarande siffror i dag skulle kunna ligga runt 20 miljarder kronor (FUTdelegationen 2007).

Bidragsbrott har dock inte förknippats med ekonomisk brottslighet. Förutom det nyss nämnda skälet att brotten begås av vanliga människor innebär det samtidigt att den tydliga kopplingen till företag saknas, vilket ofta är ett definitionsmässigt krav på ekobrott. Senare tids forskning visar dock att företag kan vara involverade $\mathrm{i}$ enskilda personers bidragsbrott genom att exempelvis konstruera en sjukpenninggrundande inkomst (ISF 2011:12). Dessutom kan bidragsbrott hålla ner svarta löner från arbetsgivare och utgör därför en inte obetydlig marknadsmässig komponent i den svarta ekonomin där företag är en förutsättning (Brå 2007:23). Till detta kommer att företag ingår i bedrägerier mot assistansersättning.

Genom att inte naturligt falla in i ekobrottsfållan har bidragsbrott i stället hanterats som ett eget område. Riksrevisionsverkets nyss nämnda rapport uppfattades som obekväm och författarna kände sig som profeter i eget land (Korsell, Hagstedt och Skinnari 2008). Snart skulle dock deras granskning omvärderas.

Under 2000-talet börjar fler och fler ställa frågan om det inte fuskas med bidragen. På några år sker plötsligt en omvälvande förändring av fuskdebatten (Johnsson 2010, Korsell, Skinnari och Hagstedt 2007). Från början är det konservativa och liberala intressen som börjar tala om fusk. Den socialdemokratiska regeringen invänder att problemet snarare är att arbetsplatserna inte är tillräckligt bra, vilket skulle leda till hälsoproblem. Men så småningom medges att det visserligen inte fuskas, men att det pågår ett visst överutnyttjande av bidragssystemen, fast i god tro. Klimatet kring fuskfrågorna hårdnar. Från det socialdemokratiska regeringshållet uppgraderas bidragsfusket till »stöld av våra gemensamma pengar«. På kort tid går regeringen från »överutnyttjande i god tro« till »stöld och bedrägeri«. Plötsligt har det blivit politiskt gångbart med hårdare tag mot bidragsfusket.

År 2005 tillkallade regeringen en delegation som ett led i ett större arbete för att stärka legitimiteten för de offentliga trygghetssystemen (FUT-delegationen, 
2005). Sedan dess har en rad initiativ tagits och utredningarna har avlöst varandra för att minska bidragsbrotten. Vi har knappast sett slutet på denna utveckling, även om debatten i dag snarare handlar om myndigheternas njugghet med att ge behövande stöd och inte att det fuskas.

\section{Företagsbot och administrativa sanktioner}

År 1972 infördes en av de viktigaste bestämmelserna på ekobrottsområdet (Zila 1992). En administrativ sanktion - skattetillägg - kan sedan dess påföras den som lämnar oriktig uppgift till beskattningen, till exempel genom att inte redovisa samtliga inkomster. Fördelen från myndigheternas sida med de nya reglerna är att Skatteverket kan besluta om skattetillägg utan att gå via åklagare eller domstol. Den viktigaste fördelen är dock att det inte förutsätts några subjektiva rekvisit för att påföra skattetillägg - uppsåt eller vårdslöshet - utan det räcker med att uppgiften objektivt sett är oriktig.

Även om skattetillägg från början skulle avse bagatellförseelser har skattetillägget med tiden fătt stort genomslag och används i praktiken i stället för straff även för skatteundandragande som gäller tämligen stora belopp. Kritik har riktats mot skattetillägget, bland annat att det leder till »dubbelbestraffning « om både straff och skattetillägg beslutas (jfr SOU 2001:25, dir. 2012:14). År 2010 lagfördes 405 personer för skattebrott (Skatteverket 2011). Den siffran ska jämföras med att det samma år fattades 154000 beslut om skattetillägg (Skatteverket 2011). De totala beloppen för dessa skattetillägg överskred en miljard kronor. Gissningsvis skulle de personer som samma år lagfördes till bötesstraff för skattebrott betala sammanlagt några hundra tusen kronor i böter. Dessa siffror visar tydligt de administrativa sanktionernas stora betydelse på skatteområdet.

Administrativa sanktioner liknande skattetillägg har senare införts på miljöoch finansmarknadsområdet och för att sanktionera kartellbildning. Från fiskus sida är ytterligare en fördel med administrativa sanktioner att de kan uppgå till väsentligt högre belopp än bötesstraff. Det är tydligt att behovet av en effektiv sanktionsform vägt tyngre på ekobrottsområdet än att uteslutande använda det mer stigmatiserande men för myndigheterna svårhanterliga straffet. Det kan också vara ett uttryck för att ekonomiska sanktioner fungerar väl mot överträdelser som i grunden motiveras av ekonomiska skäl.

Behovet av en kraftig sanktion tar sig också tydligt uttryck i bestämmelserna om företagsbot, som infördes år 1986. Lagstiftningen byggde på ett förslag från Eko-kommissionen (Ds Ju 1984:5). Sedan dess har reglerna ändrats och det har blivit lättare att påföra företagsbot. Från början tillämpades företagsbot knappast alls, men i dag med ett annat ekonomiskt synsätt har den särskilda rättsverkan i 
form av företagsbot blivit ganska vanligt. Företagsbot kan fastställas till lägst 5 000 kronor och högst 10 miljoner kronor.

Följaktligen är intresset stort att använda olika former av ekonomiska sanktioner mot ekonomisk brottslighet. Möjligen kan det också ses som ett inslag i den tillgångsinriktade brottsbekämpningen.

\section{Självreglering}

Näringslivet har i dag en betydligt positivare inställning till att motverka ekonomisk brottslighet jämfört med under det tidiga 1980-talet. Det har bland annat tagit sig uttryck i att företag inför system för att effektivare styra företaget och att skapa balans mellan styrelse, verkställande ledning och revisorer - bolagsstyrning eller corporate governance. Förebilder finns i 1980-talets USA (Lindgren 2005). Bakgrunden i både USA och Sverige var att en rad oegentligheter hade kommit fram i ljuset där »expansiva« styrelser och verkställande direktörer agerat i strid med aktieägarnas och allmänhetens intressen. Det var namn som Enron och WorldCom i USA och hemmavid, turerna kring försäkringsbolaget Skandia, Percy Barneviks pensionsersättning och vidlyftiga bonussystem. I Sverige infördes år 2005 en kod för bolagsstyrning. Den förvaltas av Kollegiet för svensk bolagsstyrning som beskriver koden på följande sätt (2012):

»Koden är ett led i näringslivets självreglering med syfte att förbättra bolagsstyrningen i svenska börsnoterade bolag. Den kompletterar aktiebolagslagen och annan offentlig reglering genom att ange en högre norm än lagens minimikrav för vad som i allmänhet kan anses utgöra god bolagsstyrning.«

Självreglering är ett vidare begrepp än bolagsstyrning och avser en frivillig anslutning av företag till formella normer (SOU 2004:47, Lindgren 2005, Larsson 2002, Larsson 2012). Dessa normer tas fram av ett privaträttsligt organ, som i exemplet med koden för bolagsstyrning. Med andra ord är självreglering ett alternativ eller komplement till lagstiftning. Fördelen med självreglering är att den är flexibel och kan snabbt justeras till följd av ändrade förhållanden. Kraven kan också normalt sättas högre än vad som gäller för tvingande lagstiftning. Självregleringen kan också vara bättre förankrad i de egna leden än en lagstiftning som kommer »utifrån«. Nackdelarna är att det kan vara svårt att få allmänhetens förtroende för ett frivilligt system.

Branschorganisationer har tagit fram etiska riktlinjer och även krav för anslutning till den egna organisationen (SOU 1997:133). Vid sidan av professionalitet omfattar auktorisationskraven ofta aspekter som ska motverka ekonomisk brotts- 
lighet. Exempelvis kan branschorganisationen granska de enskilda företagen och gå igenom deras redovisning.

Ett långtgånget exempel är byggbranschen som infört ett eget kontrollsystem på byggarbetsplatser - ID06. Genom legitimationstvång och inpasseringskontroll är det meningen att svart arbetskraft ska hållas borta (Ds 2009:43).

På korruptionsområdet har läkemedelsindustrin kommit överens om riktlinjer för att komma till rätta med det missbruk som förekom med bjudresor och konferenser för sjukvårdspersonal. Försvarsindustrin har följt efter med en egen kodex. Internationella handelskammaren har tagit fram en uppförandekodex och senast har en näringslivskod utarbetats som ger företag rådgivande vägledning när det gäller gåvor, belöningar och andra förmåner. Näringslivskoden ska tydliggöra gränserna för vad som ska utgöra tillåtna kontrakts- och relationsbefrämjande förmåner (SOU 2010:38).

\section{Helt om marsch}

Redovisningen hittills ger i huvudsak en bild av att myndigheter och lagstiftning hela tiden byggs på för att möta ekobrottsligheten. Utvecklingen kan emellertid också innebära en avveckling av tidigare reformer.

En tidig inriktning för att förebygga ekobrott var att enbart låta seriösa personer få driva näringsverksamhet. Tanken är lockande att det genom registerslagningar (vandelsprövning), utbildningskrav och andra trösklar går att hålla oseriösa personer utanför. Eko-kommissionen var inne på sådana lösningar för utsatta branscher (SOU 1984:15.) Det gällde restaurang-, transport-, bil- och städbranscherna. Förslaget genomfördes aldrig utan i stället skärptes de befintliga kraven i yrkestrafiklagen och alkohollagen. Det finns också en generell möjlighet att förbjuda en person att formellt driva näring (näringsförbud) eller att vara verksam som rådgivare (rådgivningsförbud). Särskilt från fackligt håll har dock upprepade krav rests på generella näringstillstånd och företagarkörkort.

Det har också funnits andra idéer om att försvåra för oseriösa aktörer att börja driva näring. Ett exempel gäller krav på aktiekapitalets storlek som spärr mot att aktiebolagsformen används för oseriösa syften. Vid höjningen år 1973 påpekades att den låga gränsen om $5000 \mathrm{kr}$ hade möjliggjort att aktiebolagsformen i betydande utsträckning hade använts på ett inte önskvärt sätt. Vid 1995 års höjning till $100000 \mathrm{kr}$ anfördes vidare att en väsentlig höjning av aktiekapitalet skulle kunna bidra till att motverka missbruk av aktiebolagsformen för olika slag av ekonomisk brottslighet (prop. 1993/94:196 s. 82). Nyligen har gränsen för lägsta tillåtna aktiekapital sänks från $100000 \mathrm{kr}$ till $50000 \mathrm{kr}$. Bakgrunden är att göra 
aktiebolagsformen mer tillgänglig för företagare. I dag är det viktigare att få fart på företagandet än att motverka ekonomisk brottslighet.

Frågan är dock hur effektivt det är med trösklar för att få bedriva näringsverksamhet. De flesta ekobrottslingar hamnar trots allt aldrig i kriminalregistret och bulvaner är en verksam metod för dem som föredrar att verka i kulisserna. De branscher som länge haft tillståndskrav - som restaurang och taxi - har tydliga problem med ekonomisk brottslighet.

För mindre aktiebolag har en betydande kostnad varit kravet på revision. Från och med den 1 november 2010 gäller nya regler om att små aktiebolag får välja om bolaget ska ha en revisor eller inte (SOU 2008:32). Syftet är att aktiebolagen så långt som möjligt ska få avgöra vilka tjänster som bolagen behöver för sin organisation och förvaltning. Den nya valmöjligheten omfattar 250000 aktiebolag.

Tidigare hade revisorernas betydelse för att motverka och upptäcka brott lyfts fram. Genom revisionsplikten tvingas företag att ha en ordnad bokföring och en utomstående som granskar innehållet. Så sent som år 1999 infördes till och med en anmälningsskyldighet för revisorer för brottsmisstankar som de upptäcker i samband med uppdraget (Brå 2004:4). Att ta bort revisionsplikten för ett segment av mycket små aktiebolag där många fel och brister finns i bokföringen får därför anses vara ett radikalt steg av regeringen. På ett symbolmässigt plan kan politiken uppfattas gå i fel rikting från ett ekobrottsförebyggande perspektiv.

En viktig aspekt är dock att marknaden anpassar sig till de nya förhållandena och kompenserar avregleringen av den lagstadgade revisorskontrollen. Aktiebolag kan välja att ha kvar sin revisor, inte minst för att framstå som seriösa. Det förekommer att kreditgivare ställer krav på revision eller annan kontroll för att låna ut pengar eller göra affärer. Hårdare kreditkrav och krav på bättre säkerhet kan också drabba företag som valt att stå utan revisor.

En annan uppmjukning är att det i dag är lättare att få F-skattsedel. Detta och andra exempel talar för att utvecklingen går i riktning mot att underlätta att fler blir företagare. I stället sätts kontrollen in mot dem som redan driver näring. Samtidigt kan det tolkas som att intresset har minskat för att förebygga ekonomisk brottslighet.

Förmodligen underlättar knappast dessa liberaliseringar för »riktiga« ekobrottslingar. Deras profession är trots allt att åka slalom i regelmassan och kringgå hinder. Risken är nog större att slarviga, inkompetenta och resurssvaga personer lockas in i företagarledet och sedan făr lämna det med strafföreläggande och domar på bokföringsbrott. 


\section{1. Även framåt marsch}

Även om liberala tankar styr etableringen av näringsverksamhet finns samtidigt en kraft där myndigheternas kontroll blir mer offensiv och samtidigt betungande för företagarna. Mycket talar för att denna kontroll riktad mot ekonomisk brottslighet har lånat åtskilliga drag av det arbetssätt som snarare förknippas med Polisen än myndigheter med kontroll- och tillsynsfunktioner (Korsell 2012). Tidigare nämndes telefonavlyssning, underrättelseverksamhet och spaning. Det är metoder som snarare brukar sammankopplas med organiserad brottslighet än ekobrott.

Ett tidigt exempel på offensiva insatser är den transportkontroll som Tullverket utför i egenskap av beskattningsmyndighet för punktskatter av alkoholvaror, tobaksvaror och energiprodukter (SOU 1997:86). Kontrollen får ske under pågående transport och även då varor på-, av- eller omlastas i direkt anslutning till transport. Det är en utveckling mot en »flygande kontroll«. Det finns också en liknande fältkontroll riktad mot torg- och marknadshandel. Skatteverket får genomföra oannonserade kontrollbesök för att identifiera en person som bedriver eller kan antas bedriva torg- och marknadshandel.

Många näringsidkare är numera skyldiga att använda certifierade kassaregister och erbjuda kunden ett kvitto (SOU 2005:35). Skatteverket har rätt att göra oanmälda kontroller av kassaregistren på arbetsplatserna. Dessutom får Skatteverket företa kundräkning, kontrollköp, kvittokontroll och kassainventering.

Restauranger, kaféer och frisörer är sedan några år tillbaka skyldiga att föra en personalliggare där de skriver in vilka som arbetar och när de börjar och slutar för dagen (Ds 2005:28, Ds 2009:43). Skatteverket har sedan rätt att oannonserat göra kontrollbesök för att se vilka som arbetar på stället och att granska att personalliggare finns och att den fylls i på rätt sätt. Under år 2007 utförde Skatteverket inte mindre än 31000 kontrollbesök och året därpå 17700 besök (Ds 2009:43).

\section{Underrättelsetjänsternas uppkomst}

Redan AMOB-utredningen konstaterade att ekonomisk brottslighet är svår att upptäcka. En särskild arbetsgrupp som följde i spåren av AMOB-utredningen SPANEK-utredningen - konstaterade också att den brottsupptäckande verksamheten var bristfällig och nya strategier och metoder diskuterades (SPANEK 1979). De ekorotlar som byggdes upp inom Polisen i skiftet mellan 1970- och 1980-tal ärvde dock för mycket av de gamla skatte- och bedrägerirotlarnas arbetssätt. Det var trots allt samma personer som övergick till de nya rotlarna, och så mycket spaning blev det aldrig som kunde upptäcka brott. Även regeringen slog fast att det fanns för lite utrymme för spaning (prop. 1984/85:32). 
»Det har inte varit något fel på myndigheternas ambitioner att komma åt den ekonomiska brottsligheten, men det har aldrig velat sig riktigt, «

konstaterar förre riksåklagaren och rikspolischefen Holger Romander (2000) i en tillbakablick, och fortsätter:

»Tid och krafter har gått åt för att utreda brott som har anmälts av skattemyndigheterna, konkursförvaltarna eller andra. Den dolda brottsligheten har förblivit dold och det har inte funnits förutsättningar för att på ett tidigt stadium identifiera nya hot.«

Dock har mycket hänt sedan AMOB- och SPANEK-utredningarnas tid. Tullverket var tidigt ute med att inrätta en underrättelsetjänst och under de senaste tio tjugo åren har kriminalunderrättelsetjänster byggts upp inom Polisen. Till Polisens underrättelseverksamhet hör också Finanspolisen, som i praktiken fungerar som en myndighetsgemensam underrättelsetjänst (Brå 2011:4). Det senaste tillskottet på det myndighetsgemensamma området är de nyss nämnda regionala underrättelsecentra och det nationella underrättelsecentrat (Brå 2011:20, Brå 2008:10). Under 2000-talet har även Ekobrottsmyndigheten liksom Skatteverkets skattebrottsenheter utvecklat underrättelseverksamheter.

\section{Slutsatser och framåtblick}

Behovet av att skapa nya jobb kommer rimligtvis att fortsätta och i det ligger att underlätta för företagen. Det medför att lagstiftaren undviker att krångla till det. Tidigare fanns tankar om att försöka hålla borta oseriösa personer från att bedriva näringsverksamhet. Politiken i dag är snarare att stimulera att så många som möjligt ska starta eget. När väl företagen är i drift kommer dock statsmakterna inte att lägga fingrarna emellan för att utöva kontroll. Samtidigt fortsätter säkert utvecklingen med integritetskänslig lagstiftning mot dem som misstänkts för brott. Nästa steg är att hemlig rumsavlyssning - »buggning « - kan komma att användas även mot vissa ekobrott (jfr SOU 2012:44). Motivet är att ekobrott ses som allvarlig brottlighet med nära koppling till organiserad brottslighet.

Om pengar är motivet för ekobrottslingar är pengar också motivet för brottsbekämpare och lagstiftare i välfärdens Sverige. Fortsatt kommer skatter att vara högintressant. Lagstiftningsområden med aktualitet kommer rimligtvis att även fortsättningsvis vara sådana områden som har att göra med tillgångsinriktad brottsbekämpning, som frågor om beslag, förverkande och penningtvätt. Även finansiell brottslighet är viktigt. 


\section{Lars Korsell}

En tydlig utveckling är att näringslivet tar ett större ansvar för att motverka oegentligheter och ekobrott. I dagens mediesamhälle är image viktigt och skandaler innebär ofta stor skada. För att förebygga sådana situationer är företag och deras organisationer angelägna om att framstå som seriösa och att ge bilden av att stora ansträngningar görs för att motverka missförhållanden. Det är därför inte svårt att förutspå att denna utveckling med etiska riktlinjer och självreglering kommer att fortsätta.

Däremot är det svårt att tro att självregleringen kommer att bedrivas systematiskt och utgå från någon form av genomgång av behovet på liknande sätt som tidigare refererade lagstiftningsöversyner. Förmodligen sker initiativen till självreglering som en reaktion på skandaler och debatter.

Möjligen har dessa utvecklingslinjer fört med sig att vi glömt bort de brottsförebyggande ambitionerna på ekobrottsområdet. I vart fall går det att hävda att det brottsförebyggande inslaget varit begränsat och att det är offensiva åtgärder som vunnit terräng. Det är bara att titta på satsningen mot organiserad brottslighet med dess utpräglade brottsbekämpande karaktär (Brå 2009:19).

I kampen mot organiserad brottslighet har polisens perspektiv fått dominera och de brottsförebyggande perspektiven sträcker sig knappast längre än till att hårdbevaka särskilt aktiva kriminella (targetpersoner) som finns upptagna på särskilda listor med namn som Nova och Alcatraz. I grunden vilar denna tanke och polisers individinriktade perspektiv på att gärningspersoner så snabbt som möjligt ska hamna bakom lås och bom. Om man så vill handlar det om en listigare och mer strategisk form av traditionell brottsbekämpning än att bara utreda brott. Det enda brottsförebyggande är att dessa personer har svårare att planera och utföra nya brott innanför fängelsemurarna än utanför. Något som de delar med alla andra inspärrade personer, låt vara att dem på listorna är särskilt aktiva.

Det finns mycket lite tänkande kring att exempelvis försvåra för kriminella marknader och intressera sig för de personer som gör affärer med gärningspersonerna eller på annat sätt möjliggör deras brottslighet. Även ekobrottsbekämpningen har numera sina egna listor på targetpersoner.

Samtidigt finns definitivt en potential att lägga större tonvikt vid brottsförebyggande åtgärder, och frågan är om det inte i framtiden skymtar ett ökat intresse för att arbeta förebyggande. Särskilt om kommunerna engageras mer, vilket jag återkommer till.

På senare tid har 1970-talets perspektiv om kopplingen mellan ekonomisk och organiserad brottslighet kommit tillbaka med tydlig styrka. Det har också tagit sig praktiska former genom de regionala underrättelsecentra (RUC), nationella underrättelsecentrat (NUC), operativa rådet och samverkansrådet där myndigheter 
samverkar kring organiserad och ekonomisk brottslighet, låt vara med en viss tyngdpunkt mot traditionell organiserad brottslighet. Trots denna klarsynthet om hur organiserad och ekonomisk brottslighet inte sällan går in i varandra väljer regeringen att $\mathrm{i}$ ännu högre grad slå vakt om Ekobrottsmyndigheten och låta myndigheten växa. Samtidigt talar mycket för att regeringen kommer att införa en nationell polis med regional indelning (SOU 2012:13). Vid samma tillfälle som en nationell polis införs hade det varit logiskt att ta steget fullt ut och låta ekobrotten gå tillbaka till polisorganisationen och inrätta ett antal specialåklagarkammare för ekonomisk brottslighet, men med en vidare definition av vilka brottstyper som räknas dit.

Ett rimligt framtidsscenario är att diskussionen om var ekobrotten organisatoriskt hör hemma inte är avslutad i och med den senaste utredningen (SOU 2011:47). Under de närmaste åren kommer rättsväsendet dock att ha fullt upp med att organisera om polisen (SOU 2012:13). När den reformen satt sig kommer ekobrotten upp till ny diskussion. Argumenten från de båda utredningarna som föreslog att Ekobrottsmyndigheten skulle avskaffas respektive att införa en nationell polis kommer då att dammas av och fräschas upp (SOU 2007:8, SOU 2012:13).

Skattebrottsenheternas vara eller icke vara är dock svårare att sia om. Det finns en stark koppling mellan skattebrottsenheterna och Skatteverkets fiskala verksamhet med revision och annan kontroll. Visserligen upprätthålls sekretess mellan brottsbekämpning och fiskal verksamhet, men samarbetet handlar snarare om strategier och riskbedömningar som gynnar de båda benen. Det skulle tala för att skattebrottsenheterna får vara kvar. Ytterligare ett argument kan vara att skattefrågorna kommer att bli än viktigare för att klara kommande utmaningar (växande åldrande befolkning, internationell konkurrens, miljöhot etc.). Budordet kommer då att vara att Skatteverkets intressen får styra, och myndigheten vill säkert inte släppa över skattebrottsenheterna till en osäker framtid inom Polisen. Resonemanget kan vara att staten varken står eller faller med en mindre effektiv Polis, men handlar det om att driva in skatter är det blodigt allvar.

En tydlig utveckling är att myndigheterna sett ett ökat behov av samverkan. Samtidigt har brottsbekämpningen fătt upp ögonen för »nya« myndigheter att samarbeta med, som Försäkringskassan och Kronofogden. Samarbetet kommer också att fortsätta och utvecklingen bör gå mot att även kommuner och kommunala förvaltningar tydligare dras in i ekobrottsfrågorna (Brå 2010). Kommunerna är inte enbart centrala aktörer när det gäller upphandling av bygg- och anläggningsarbeten, städuppdrag och transporter, samtliga områden med problem med storskaligt svartarbete. Kommunerna tillhandahåller också lokaler och utrymmen 
för handel, utför tillsyn och kontroll, exempelvis enligt livsmedels-, miljö- och alkohollagstiftningarna samt svarar för planläggning. Kontaktytorna mot ekonomisk brottslighet är därmed betydande. Dessutom har kommunerna ett självändamål att ta tag i framför allt skattebrotten i syfte att trygga det egna beskattningsunderlaget. Med tanke på de kommunala skandaler som inträffat finns också ett utrymme för att stärka förvaltningarna mot korruption och andra oegentligheter.

Redan i dag har kommunerna en central roll för att motverka traditionell brottslighet, framför allt i det offentliga rummet, och arbeta med att öka människors trygghet i den lokala miljön. Framtiden bör därför se ett ökat engagemang mellan statliga myndigheter och kommuner.

Sedan AMOB-utredningen på 1970-talet tog fram de första skisserna för en modern ekobrottsbekämpning har flera viktiga förändringar skett. Ett stort steg är att underrättelsetjänster utvecklats. Härigenom kommer förmågan att upptäcka och kartlägga brott ytterligare att förstärkas. Det handlar då inte enbart om underrättelseverksamhet utan om kontroll i vid mening (Korsell 2012). Exempelvis arbetar Skatteverket mycket aktivt med att ta fram riskmodeller för att bättre kunna styra kontrollverksamheten. På bidragsområdet har en kraftig utveckling skett av kontrollen. För bara tio år sedan förekom knappast någon kontroll alls.

På underrättelseområdet har som nämnts utvecklingen varit närmast explosionsartad. Det är knappast en realistisk och effektiv utveckling med tanke på att verksamheterna delvis överlappar varandra. Samtidigt bildar varje underrättelseverksamhet sitt eget stuprör. Informationsutbyte blir därmed en central fråga. Det var också bakgrunden till det första regionala underrättelsecentrat som bildades i Göteborg (Brå 2008:10). Genom att underrättelsehandläggare från olika myndigheter sitter i samma rum ökar förutsättningarna för en bättre kartläggning när alla kan dra sitt strå till stacken.

Däremot finns det anledning att se över stuprörseffekten av alla underrättelseverksamheter som byggts upp på senare tid. Olika modeller är tänkbara, med ökat samarbete och delgivning som med de regionala underrättelsecentra eller att sammanslagningar sker av underrättelsetjänster. Under alla omständigheter måste något göras för att minska splittringen.

En utveckling på senare tid är att uppmärksammad kriminalitet på ekobrottsområdet eller som ligger nära ekobrott inte handläggs av Ekobrottsmyndigheten utan av det reguljära polis- och åklagarväsendet. Det gäller korruptionsbrottsligheten som i högsta grad handlar om ekonomisk brottslighet eftersom brotten sker inom ramen för organisationer. De flesta bedrägerier samt bidragsbrott handläggs också utanför Ekobrottsmyndigheten. 
Samtidigt kommer Ekobrottsmyndigheten att växa och få nationell kompetens för sina måltyper. Risken är uppenbar att Polisen och Åklagarmyndigheten fortsätter att rusta ned sin kompetens på ekobrottsområdet med motivet att Ekobrottsmyndigheten finns. Om ett ökat fokus kommer att riktas mot bedrägerier kan dock denna utveckling hejdas. Ett rimligt antagande är att det reguljära polis- och åklagarväsendet inom en snar framtid kommer att ägna bedrägerierna större intresse. Vad som talar för det är också att det finns en koppling till organiserad brottslighet, som på ett allmänt plan i högre grad närmar sig ekobrott.

Ytterligare ett motiv till att Polisen och Åklagarmyndigheten kommer att satsa mer på ekobrott är inriktningen på tillgångsinriktad brottsbekämpning som har en ekonomisk inriktning. Från tillgångar i form av konton, fastigheter och bolagsinnehav är avståndet inte alltför långt till ekobrott.

Däremot kommer uppmärksamheten kring korruption inte att nämnvärt påverka polis och åklagare på ett allmänt plan eftersom det är specialenheter som handlägger sådana ärenden. Specialenheter arbetar också med miljö- och arbetsmiljöbrott, som också bör räknas in under ekobrottsbekämpningen.

Återblicken av fyrtio års ekobrottsbekämpning visar ett tydligt mönster av större initiativ från regeringens sida i form av strategier mot ekobrott och lagstiftningsöversyner. Det började med uppdraget till Brå, som övergick till Ekokommissionen och tio år senare kom strategin om samlade åtgärder mot ekonomisk brottslighet. Snart har det gått tjugo år sedan det senaste åtgärdspaketet började sjösättas. Är det dags för ett nytt initiativ? Och vad skulle det i så fall innehålla?

Det som talar för att återigen lyfta fram ekobrott som ett särskilt område är de stora skador som brottsligheten för med sig. Tidigare nämndes det ökande behovet av att säkra skattebaserna, de finansiella systemens större betydelse för välfärden, behovet av att slå vakt om trygghetssystemens legitimitet och att motverka korruption i offentlig sektor. Till det kommer bedrägeribrottsligheten som kan förväntas bli ett allt större gissel.

Det som talar mot ett särskilt ekobrottspaket är svårigheten att lyfta fram ekobrott som ett eget särskilt område. Från regeringens sida ligger det nära till hands att definiera ekobrott som de brottstyper som Ekobrottsmyndigheten handlägger. Det går knappast att lansera en ekobrottsstrategi där de flesta aktuella brottstyper ligger utanför Ekobrottsmyndighetens målområde (korruption, bidragsbrott och bedrägerier).

Min gissning är att framtiden snarare kommer att lyfta fram specifika områden än ekobrott generellt. Det kan därför komma en handlingsplan mot korruption och en annan mot bedrägerier. Egendomligt nog skulle därför ekobrottens tid som 
politiskt slagord vara förbi tack vare att en särskild myndighet inrättats mot just ekobrott. Men osvuret är bäst. Säkert är dock att de kommande fyrtio åren kommer att bli innehållsrika och innebära många överraskningar. Den som lever făr se.

\section{Note}

1. Lars Korsell (LL.D.) is head of The Economic and Organised Crime Research Unit at the Swedish National Council for Crime Prevention in Stockholm.

\section{Referenser}

Alalehto, T. (1999). Motiv eller tillfälle? En studie om ekonomisk brottslighet $i$ restaurangbranschen. Stockholm: Atlas.

Alalehto, T. (2003). Fiffelstrategier vid ekonomisk brottslighet. Lund: Barrs förlag.

Boström, J. och Nilsson, J. (2006). Lagen om marknadsmissbruk. Ett verktyg för att motverka ekonomisk brottslighet. Avdelningen för rättsvetenskap vid Luleå tekniska högskola.

Bromander, L. (2007). Uthyrning av arbetskraft - Ett rättssociologiskt perspektiv på en flexibilitetsstrategi. Handelshögskolan vid Göteborgs universitet.

Brå 2005:10. När olyckan inte är framme. Bedrägerier om allmän och privat försäkring. Stockholm: Brottsförebyggande rådet.

Brå 2007:4. Vart tog alla pengarna vägen? En studie om narkotikabrottslighetens ekonomihantering. Stockholm: Brottsförebyggande rådet.

Brå 2007:23. Fusk med A-kassa. Motiv, omfattning och åtgärder. Stockholm: Brottsförebyggande rådet.

Brå 2007:21. Korruptionens struktur i Sverige, del 1: "Den korrupte upphandlaren « och andra fall om mutor, bestickning och maktmissbruk. Stockholm: Brottsförebyggande rådet.

Brå 2007:27. Organiserat svartarbete i byggbranschen. Stockholm: Brottsförebyggande rådet.

Brå 2008:6. Samverkan mot bidragsbedrägerier. Exemplet Västmanland och Skåne. Stockholm: Broffsförebyggande rådet.

Brå 2008:10. Tillgångsinriktad brottsbekämpning. Myndigheternas arbete med att spåra och återföra utbyte av brott. Stockholm: Brottsförebyggande rådet.

Brå 2009:19. Polisens satsning mot organiserad brottslighet. En utvärdering av 43 projekt. Stockholm: Brottsförebyggande rådet.

Brå 2011:4. Penningtvätt. Rapportering och hantering av misstänkta transaktioner. Stockholm: Brottsförebyggande rådet.

Brå (2010). Lokal organiserad brottslighet. En handbok. Stockholm: Brottsförebyggande rådet.

Brå 2011:7. Storskaliga skattebrott. En kartläggning av skattebrottslingens kostnader. Stockholm: Brottsförebyggande rådet.

Brå 2011:20. Bekämpning av organiserad brottslighet. Utvärdering av den myndighetsgemensamma satsningen mot grov organiserad brottslighet. Stockholm: Brottsförebyggande rådet.

Citron, B-M. (1999). Sölve \& Co. Korruptionsskandalen i Motala. Stockholm: Norstedts.

Cristiansson, T. (2009). »Grova brott kan bekämpas med Al Capone-metoden. « Expressen den 4 november 2009 .

dir. 1982:101. Atgärder mot ekonomisk brottslighet mm. 
dir. 2012:14. Stärkt rättssäkerhet vid skatteförfarandet.

Ds Ju 1984:5. Företagsbot. Stockholm: Justitiedepartementet.

Ds 1996:1. Effektivare ekobrottsbekämpning. Stockholm: Justitiedepartementet.

Ds 1997:23. Skattekriminal. Stockholm: Justitiedepartementet.

Ds 2005:28. Skattefusk, effektivitet och rättvisa - utökad skattekontroll i vissa branscher och diskussioner rörande schabloniserade inslag $i$ beskattningen. Finansdepartementet. Stockholm: Fritzes.

Ds 2009:43. Närvaroliggare och kontrollbesök. Finansdepartementet. Stockholm: Fritzes.

EBM-utredningen (1997). Ekobrottsmyndigheten och den nya organisationen för bekämpning av ekonomisk brottslighet. Rapport från EBM-utredningen 1997-05-14. Stencil.

FUT-delegationen (2007). Vem fuskar och varför? Om attityder till bidragsfusk $i$ Sverige. Rapport 6. Stockholm: Fritzes.

Hetzler, A. (2001). »Insiderbrott och reglering av värdepappersmarknaden - en värdefråga? « I: Appelgren, L. och Sjögren, H. (red.). Ekonomisk brottslighet och nationalstatens kontrollmakt. Hedemora: Gidlund.

ISF 2011:12. Bidragsbrott och skattekriminalitet. Välfärdens dubbla kriminalitet. Stockholm: Inspektionen för socialförsäkringen.

Johansen, P.O. (2004). Den illegale spriten. Fra forbudstid til polstreik. Oslo: Unipub forlag.

Johansson, P. (2004). I skandalers spår. Minskad legitimitet i svensk offentlig sektor. Akademisk avhandling. Förvaltningshögskolan vid Göteborgs universitet.

Johnson, B. (2010). Kampen om sjukfrånvaron. Lund: Arkiv förlag.

Kollegiet för svensk bolagsstyrning (2012). Hemsida www.bolagsstyrning.se

Korsell, L. (1998). »Inkomstbegreppet i socialförsäkrings- och bidragssystemen.« I: Skattenytt, nr 3, årgång 48. s. 115-125.

Korsell, L. (2000). »Ekobrott, liksom!« Svensk Juristtidning, s. 933-965.

Korsell, L. (2003). Bokföringsbrott - en studie i selektion. Akademisk avhandling. Kriminologiska institutionen vid Stockholms universitet.

Korsell, L. (2005). »Fiffel och fusk i slott och koja.« I: Sjöstrand, G. Fiffel-Sverige. Sociologiska perspektiv på skandaler och fusk. Malmö: Liber.

Korsell, L. (2006). »Ekonomisk och organiserad brottslighet - ett kriminalpolitiskt drama i sju akter.« Nordisk Tidskrift for Kriminalvidenskab, s. 249-273.

Korsell, L. (2008). »Hur organiserad är den organiserade brottsligheten?« I: Alalehto, T. och Larsson, D. (red), Den ljusskygga ekonomin: Organiserad och ekonomisk brottslighet. Umeå: Sociologiska institutionen vid Umeå universitet.

Korsell, L. (2010). »Strategier mot organiserad brottslighet.« I: Alalehto, T. och Larsson, D. (red.). Vinddriven kriminalitet på en vinddriven marknad. Ekonomisk och organiserad brottslighet. Borås: Recito Förlag.

Korsell, L. (2012). »Formell kontroll av informell ekonomi«. I: Pettersson, T. och Pettersson, L. (red.). Kontrollens variationer. Lund: Studentlitteratur.

Korsell, L. och Nilsson, M. (2003). Att förebygga fel och fusk. Metoder för reglering och kontroll. Stockholm: Norstedts Juridik.

Korsell, L., Hagstedt, J. och Skinnari, J. (2008). »Från kelgrisar till styvbarn - Fusket med välfärdssystemen.« Nordisk Tidskrift for Kriminalvidenskab, s. 21-38, nr. 95. 
Korsell, L., Skinnari, J. och Vesterhav, D. (2009). Organiserad brottslighet i Sverige. Malmö: Liber.

Larsson, P. (2002). A veilede, overtale eller straffe. Oslo: Det kriminalitetsforebyggende råd (KRÅD).

Larsson, P. (2012). »Regulating Corporate Crime, from penal punishment to self regulation.« Kommande artikel.

Lindgren, S- $\AA$ (2000). Ekonomisk brottslighet. Ett samhällsproblem med förhinder. Lund: Studentlitteratur.

Lindgren, S-A (2005). »Socialt kapital, bolagsstyrning och självreglering.« I: Sjöstrand, G. Fiffel-Sverige. Sociologiska perspektiv på skandaler och fusk. Malmö: Liber.

Lindstedt, G. (2000). Svindlande affärer: historien om Trustor. Stockholm: DN.

Lisinski, S. (2010). »Stor mututredning skakar Kriminalvården.« Dagens Nyheter den 28 maj 2010.

Ludvigsson, K. (2008). Korruption i Sverige. Betydelsen av organisation och socialt kapital. Sociologiska institutionen vid Lunds universitet.

Posener, J. (2004). Internationellt efterlyst: mitt liv efter Trustor. Stockholm: TV3 reportage.

Prins Pierre [pseudonym för Lindholm, F.] (1893). Stockholmsdetektiven. Stockholm: Askerberg.

Prop. 1984/85:32. Proposition om riktlinjer för det framtida arbetet mot ekonomisk brottslighet $\mathrm{mm}$.

prop. 2005/06:59. Företagsbot.

prop. 2009/10:61. En sänkning av kapitalkravet för privata aktiebolag.

prop. 2009/10:204. En frivillig revision.

prop. 2008/09:62. F-skatt åt fler.

Riksdagens revisorer (1993/94:6). Den ekonomiska brottsligheten och rättssamhället. Stockholm: Riksdagens revisorer.

Riksdagens revisorer (1994/95:RR4). Insatser mot den ekonomiska brottsligheten. Stockholm: Riksdagens revisorer.

RRV 1995:32. Fusk - systembrister och fusk $i$ välfärdssystemet. Stockholm: Riksrevisonsverket.

Romander, H. (2000). »Lagstiftningsöversynen och dess bakgrund.« I: Korsell, L. Perspektiv på ekobrottsligheten. Antologi. Stockholm: Brottsförebyggande rådet.

RSV 1983:1. Skatter och skattekontroll. Förutsättningar för en effektiv kontrollverksamhet. PLAN-projektet. Stockholm: Riksskatteverket.

RSV 1995:9. Skattemyndigheternas medverkan i en effektivare ekobrottsbekämpning. Stockholm: Riksskatteverket.

Ruggiero, V. (1996). Organized and Corporate Crime in Europe. Offers that Can't Be Refused. Dartmouth: Aldershot.

Shapiro, S. (1990). »Collaring the Crime, Not the Criminal. Reconsidering the Concept of White-Collar Crime«. American Sociological Review. Vol. 55, 346-365.

Skatteverket (2011). Skatter i Sverige. Skattestatistisk årsbok 2011. Solna: Skatteverket.

Skr. 1994/95:217. Regeringens skrivelse till riksdagen. Samlade åtgärder mot den ekonomiska brottsligheten.

SOU 1983:75. Företagens uppgiftslämnande för beskattningsändamål. Stockholm: Fritzes.

SOU 1997:86. Punktskattekontroll av alkohol, tobak och mineralolja mm. Stockholm: Fritzes. 
SOU 1997:127. Straffansvar för juridiska personer.

SOU 1997:133. Branschsanering och andra åtgärder mot ekonomisk brottslighet. Stockholm: Fritzes.

SOU 2001:25. Skattetillägg $\mathrm{mm}$. Stockholm: Fritzes.

SOU 2004:47. Näringslivet och förtroendet. Stockholm: Fritzes.

SOU 2005:35. Krav på kassaregister-Effektivare utredning av ekobrott. Stockholm: Fritzes.

SOU 2007:8. Nya förutsättningar för ekobrottsbekämpning. Stockholm: Fritzes.

SOU 2008:32. Avskaffande av revisionsplikten för små företag. Stockholm: Fritzes.

SOU 2010:38. Mutbrott. Stockholm: Fritzes.

SOU 2011:47. En samlad ekobrottsbekämpning. Stockholm: Fritzes.

SOU 2012:13. En sammanhållen svensk polis. Stockholm: Fritzes.

SOU 2012:44. Hemliga tvångsmedel mot allvarliga brott. Stockholm: Fritzes.

SPANEK (1979). Några synpunkter på spaningsmetoder. Arbetsgruppen angående spaning mot ekonomisk brottslighet (SPANEK). Stockholm: Rikspolisstyrelsen.

Statskontoret 2012:20. Köpta relationer. Om korruption i det kommunala Sverige. Stockholm: Statskontoret.

Sutherland, E.H. (1949). White-Collar Crime. New York: Holt, Rinehart and Winston.

Svensson, B, (1982). De ekonomiska brotten. Apropå 3:25.

SVT (2009). »Han är kritisk mot bristande resurser hos utredare.« Uppdrag granskning den 10 juni 2009 på SVT:s hemsida. Sveriges Television.

Wesser, E. (2001). »Har du varit ute och shoppat, Jacob? «: En studie av Finansinspektionens utredning av insiderbrott under 1990-talet. Sociologiska institutionen vid Lunds universitet.

Wästerfors, David. (2004). Berättelser om mutor - Det korruptas betydelse bland svenska affärsmän i Öst- och Centraleuropa. Stockholm/Stehag: Brutus Östling Bokförlag Symposium.

Zila, J. (1992). I stället för straff: sanktionsavgifter som kriminalpolitiskt medel mot bagatellbrottslighet. Akademisk avhandling. Stockholm: Juristförlaget.

Örnemark Hansen, Helen (1998). Penningtvätt. Ett urvattnat begrepp? Stockholm: Norstedts juridik. 